ljtihad, Jurnal Wacana Hukum Islam dan Kemanusiaan

Vol. 18, No. 1 (2018), pp. 1-16, doi : 10.18326/ijtihad.v18i1.1-16

\title{
Justifikasi hukum Islam atas pajak dalam perspektif hukum dan ekonomika
}

\author{
Arvie Johan \\ Departemen Hukum Pajak Fakultas Hukum Universitas Gadjah Mada \\ Jl. Sosio Yustisia No. 1, Bulaksumur, Sleman, D.I.Y. \\ Email:arviejohan@mail.ugm.ac.id \\ DOI: 10.18326/ijtihad.v18i1.1-16
}

In the earliest period of islam, islam introduced jizya, kharaj, and 'ushr as taxes. In its development, taxes are expanded into more complex types such as: income tax, value added tax, land tax, and customs. This expansion of tax base requires justification of how extent islamic law covers scope for expansions of tax base. This paper uses a law and economics approach to examine the range of islamic law to conform scope for expansions of tax base. The paper scrutinises in advance a common dilemma between Islamic law and law and economics in dealing with taxes: budgetair and deadweight loss. To achieve welfare, good taxes concern several aspects, among other: a large number of tax object, cross demand elasticity, a impact of reducing the gap, and low cost administration.

Islam awal mengenalkan jizyah, kharaj, dan 'ushr sebagai pajak. Dalam perkembangannya, pajak diperluas ke dalam jenis yang lebih rumit seperti: pajak penghasilan, pajak pertambahan nilai, pajak tanah, bea, dan cukai. Ini memerlukan justifikasi sejauhmana hukum islam mengakomodir perluasan pajak. Tulisan ini menggunakan pendekatan hukum dan ekonomika untuk memeriksa jangkauan yang diberikan hukum Islam terhadap perluasan pajak. Tulisan mengemukakan adanya kesamaan dilematis antara hukum islam dan hukum dan ekonomika dalam menghadapi keberadaan pajak: budgetair dan deadweight loss. Untuk mencapai kemaslahatan, maka pajak yang baik memperhatikan: perbanyakan obyek pajak, elastisitas permintaan silang, dampak yang mereduksi kesenjangan, dan pengadministrasian berbiaya rendah.

Keywords: tax; islamic law; law and economics

\section{Pendahuluan}

Pajak merupakan konsep yang sangat tua. Setidak-tidaknya pemungutan pajak sudah dimulai sejak Scorpion King I (Bardopoulus, 2015: 22). Pada masa pra-islam pajak dipungut oleh Quraish 
ljtihad: Jurnal Wacana Hukum Islam dan Kemanusiaan, Volume 18, No. 1, Juni 2018: 1-16

dari rombongan yang datang ke Makkah, yang akumulasi perolehannya digunakan untuk mendukung aktivitas perdagangan (Ismael dan Ismael, 2011: 45). Quraish merupakan suku bangsa arab keturunan Ibrahim yang berkuasa di Makkah (Haekal, 1992: 32-45). Berbeda dengan Makkah, di Madinah pajak dipungut oleh penguasa Madinah dari rombongan yang melintas sebagai kompensasi perbolehan melintas serta suplai bagi tentara penguasa Madinah (Yarshatar, 2000: 600).

Pada saat kedatangan islam, pajak demikian berkembang serta dibedakan menjadi jizyah, kharaj, dan 'ushr (P3EI UII, 2015: 488-489). Jizyah ialah kewajiban pajak kepala yang dibayarkan non-muslim ahli kitab untuk perlindungan harta, jiwa, kebebasan menjalankan agama, serta kebebasan dari wajib militer. Kharaj adalah pajak atas tanah yang dipungut dari non-muslim ahli kitab, yang dikenakan berdasarkan luas tanah atau tanaman atau hasil produksi. Ushr ialah bea impor yang dikenakan kepada semua pedagang yang melintasi perbatasan negara.

Mengingat perkembangan di atas, tidak dapat disangkal bahwa islam mengenal beberapa bentuk pajak. Namun sejak kemunculannya, pajak telah diperluas ke dalam jenis yang lebih rumit seperti: pajak penghasilan, pajak pertambahan nilai, pajak tanah, bea, dan cukai. Perluasan demikian membuat justifikasi pajak menurut hukum islam menjadi lebih rumit. Masalah utamanya adalah kepercayaan bahwa perluasan pajak berasal dari barat dan bukan dari sumber hukum islam (Matar, 2015: 119-127).

Berkaitan dengan hal tersebut, tulisan ini akan memeriksa sejauh mana justifikasi pajak menurut hukum Islam dengan menggunakan pendekatan hukum dan ekonomika. Hukum dan ekonomika merupakan aliran ilmu hukum yang memanfaatkan teori ekonomi untuk memeriksa serta menentukan hukum yang ideal (Mercuro dan Medena, 1999: 3). Hukum dan ekonomika memandang tujuan paripurna hukum adalah kesejahteraan total. Tujuan demikian sesuai dengan tujuan tertinggi hukum islam untuk mencapai kemaslahatan bersama (Yahya dan Fatcurrahman, 1986: 333).

Setelah pendahuluan, tulisan akan mendiskusikan perluasan pajak yang dikenali melalui jitihad ahli hukum Islam. Berikutnya tulisan akan mendiskripsikan bagaimana ilmu ekonomi menghadapi keberadaan pajak. Diskripsi menyangkut dilema keberadaan pajak: di satu sisi ia dibutuhkan untuk menegakkan hak tetapi di sisi lain ia membuat individu menderita. Terakhir, tulisan akan menunjukkan pentingnya kehati-hatian dalam perluasan pajak. Ini 
Justifikasi hukum Islam atas pajak dalam perspektif hukum dan ekonomika (Arvie Johan)

untuk mencapai perluasan pajak yang optimal dari dilema keberadaan pajak.

\section{Pajak menurut hukum Islam}

Diskusi mengenai pajak lebih pada persoalan mu'amalah daripada ibadah (P3EI UII, 2015: 499-500). Ia berkembang melalui ijtihad, sehingga pembangunannya bersifat pragmatis dan tidak rigid. Misalnya pada masa kekhalifahan Umar bin Khathab yang memungut jzzyah dari non-muslim bukan ahli kitab karena non-muslim ini juga mendapat perlindungan jiwa dan harta sebagaimana non-muslim ahli kitab (as-Sallabi, 2007: 443-448). Demikian juga ketika Umar bin Khathab meniadakan tanah kharaj, karena tanah tersebut diputuskan untuk dikuasai negara dan selanjutnya disewakan. Pada masa itu Umar bin Khathab juga menaikkan tarif 'ushr atas barang yang tidak penting, dan menurunkan tarif 'ushr untuk barang yang penting (Al-Haritsi, 2015: 580). Penerimaan dari ketiganya digunakan untuk membiayai keperluankeperluan negara.

Sejalan dengan perkembangan zaman dan kompleksitas masyarakat, kebutuhan keuangan negara untuk membiayai urusan menjadi semakin meningkat. Guna menutup kebutuhan tersebut, islam memperbolehkan perluasan pajak berupa pungutan bagi individual muslim. Perbolehan ini dikenali melalui pendapat empat mazhab dalam islam. Terminologi untuk perluasan pajak ini dikenal dengan berbagai istilah seperti daribah, al-wazaif, al-nawaìi, dan al-kulaf al-sultāniyyah (Madaniy, 1994: 31).

Mazhab Hanafi menghalalkan perluasan pajak dengan memperhatikan: (1) kewajiban menghadirkan kemaslahatan rakyat; (2) uang negara bukan milik pemerintah tetapi amanat Allah yang harus dijaga dan penggunaannya sejalan dengan kepentingan rakyat; dan (3) pungutan hanya dikenakan sebatas kemampuan rakyat (Chamid, 2017: 161). Selanjutnya mazhab Maliki memperbolehkan perluasan pajak bilamana terdapat kebutuhan mendesak untuk mendukung kesejahteraan dan kemakmuran suatu negara (Gusfahmi, 2011: 158; Saeed, 2014: 124).

Berikutnya mazhab Syafi'i memperbolehkan perluasan pajak, sepanjang keuangan negara (yang diperoleh melalui jizyah, kharaj dan 'ushr) tidak cukup untuk membiayai kebutuhan negara (Ghazantar dan Islahi, 2011: 51-53). Terakhir, mazhab Hanbali menghalalkan perluasan pajak sebagai sumber penerimaan negara sepanjang itu untuk kesejahteraan umum 
ljtihad: Jurnal Wacana Hukum Islam dan Kemanusiaan, Volume 18, No. 1, Juni 2018: 1-16

(Wibisana, 2016: 104).

Berkaitan dengan pertanyaan apakah zakat dapat menggantikan pajak, Yusuf Qardhawi berpendapat bahwa keduanya adalah kewajiban yang berbeda satu sama lain. Zakat merupakan pilar islam berdimensi ibadah, sementara pajak lebih kebutuhan yang berpijak dari keniscayaan bahwa negara memerlukan biaya operasional (Qardhawi, 2000: 318-320). Tanpa penutupan biaya operasional, sulit bagi negara untuk mensejahterakan rakyatnya (as-Sadr, 1984: 143).

Sekalipun perluasan pajak merupakan keniscayaan, tetapi terdapat penentang perluasan tersebut. Penentang mendasarkan argumen pada: (1) pemungut pajak - al-maks - adalah orang tercela; (2) tidak ada perintah eksplisit bagi individu muslim untuk membayar hal lain selain zakat; dan (3) hak milik tidak dapat beralih kecuali perintah Allah SWT atau pertukaran sukarela (Said, 2005: 139-140).

Ketiga argumen diatas mengandung kelemahan: (1) sebagian besar hadis yang dijadikan sandaran terkait pemungut pajak tercela (al-maks) tidak dapat dipertanggungjawabkan kesahihannya, dan sebagian kecil yang sahih lebih tepat ditafsirkan sebagai pemungut pajak yang zalim; serta (2) perintah membayar pungutan pajak atau mengalihkan hak milik dapat disimpulkan dari kewajiban negara untuk menghadirkan kemaslahatan total yang membutuhkan biaya.

Berangkat dari kedua dalil pembelaan tersebut, maka perluasan pajak diperbolehkan sepanjang memenuhi persyaratan-persyaratan berikut: adanya kebutuhan menutup anggaran negara dan pemungutan tidak menimbulkan penderitaan pembayar pajak (Kahf, 1983: 145155; Al-Mishri, 2006: 159-163).

\section{Rasionalitas ekonomi keberadaan pajak}

Hak adalah kepentingan yang dilindungi oleh hukum, sementara kepentingan ialah tuntutan perorangan atau kelompok yang diharapkan untuk dipenuhi (Mertokusumo, 2005: 43). Definisi demikian berangkat dari persyaratan relasional mengenai hak: subyek, substansi, landasan, dan tujuan (Shapiro, 2006: 16). Sehingga ketika berbicara mengenai hak, muncul pertanyaan: siapa yang berhak, hak untuk apa, hak atas dasar apa, dan hak untuk tujuan apa. Persyaratan relasional menunjukkan bahwa makna hak tidak terpisahkan dari makna legitimasi. 
Ketika makna hak melekat pada makna legitimasi, maka hak mengandung biaya. Misalnya ketika terjadi perampokan, dibutuhkan pengeluaran publik untuk menutup ketakutanketakutan yang timbul dari kejadian tersebut (Becker, 1993: 390). Ketakutan bukan hanya ditanggung korban, tetapi juga individu-individu lain dalam masyarakat. Dari mana pengeluaran publik tersebut dibiayai? Salah satunya dari pajak. Ini juga menunjukkan bahwa pemulihan mengandung biaya sebagaimana hak mengandung biaya.

Dalam skala luas, negara membutuhkan pemasukan untuk membiayai tujuan dan citacita bangsanya (Soehino, 2005: 146). Sebagai contoh, tujuan Negara Indonesia sebagaimana terumus pada Alinea IV Pembukaan UUD 1945, pencapaiannya memerlukan biaya yang salah satunya diperoleh dari sektor pajak. Dalam skala lebih luas, Perserikatan Bangsa-Bangsa (PBB), membutuhkan pemasukan dari anggota-anggotanya untuk membiayai tujuan-tujuannya. Negara Indonesia sebagai anggota PBB, membayar iuran yang perolehan iurannya didapat melalui pajak.

Konsekuensi biaya hak sebagaimana ditunjukkan diatas memperlihatkan secara jelas proposisi yang saling berhubungan, bahwa hak tergantung pada kemauan negara untuk memungut pajak dan melakukan pengeluran publiknya (Holmes dan Sunstein, 1999: 61). Dengan pemahaman demikian, maka tidak penting lagi apakah hak sebagai partisipasi rencana Ilahi atau bukan, yang pasti legitimasinya bahkan melalui negara ultra minimalis sekalipun tetap memerlukan pajak (Keraf, 1997: 21; Nozick, 1999: 26-27).

Berangkat dari ketiga alinea sebelumnya, dapat dikatakan bahwa pajak dipahami sebagai suatu metode yang digunakan untuk membayar pelayanan publik (Kaplow, 2008: 14-15). Pemahaman demikian berangkat dari kenyataan bahwa pelayanan publik membutuhkan biaya, sehingga tanpa penutupan biaya, niscaya tidak ada perlindungan kepentingan individu atau kelompok melalui alat-alat negara (Friedman, 1993: 1). Pemahaman demikian juga dapat menjelaskan tujuan pemerintah meminta ketaatan pajak, yakni untuk menekan free-rider (individu yang menolak membayar pajak, tetapi menerima pelayanan publik sebagaimana pembayar pajak).

Hanya saja pemahaman diatas tidaklah cukup, karena pajak membuat pembayar pajak menjadi menderita akibat perpindahan sumber daya individualnya ke pemerintah. Penurunan bobot mati (dead weight loss) hadir ketika surplus yang didapat menjadi hilang akibat pemungutan 
ljtihad: Jurnal Wacana Hukum Islam dan Kemanusiaan, Volume 18, No. 1, Juni 2018: 1-16

pajak (Salanie, 2003: 15-16). Sebagai ilustrasi: sebelum diberlakukan pajak, harga kentang yang terbentuk di pasar adalah Rp. 10.000,- / kg. Pada posisi ini baik pelaku usaha maupun konsumen dalam kondisi surplus. Ilustrasi dapat digambarkan sebagai berikut.

\section{Gambar 1.}

Kondisi Pre-Tax

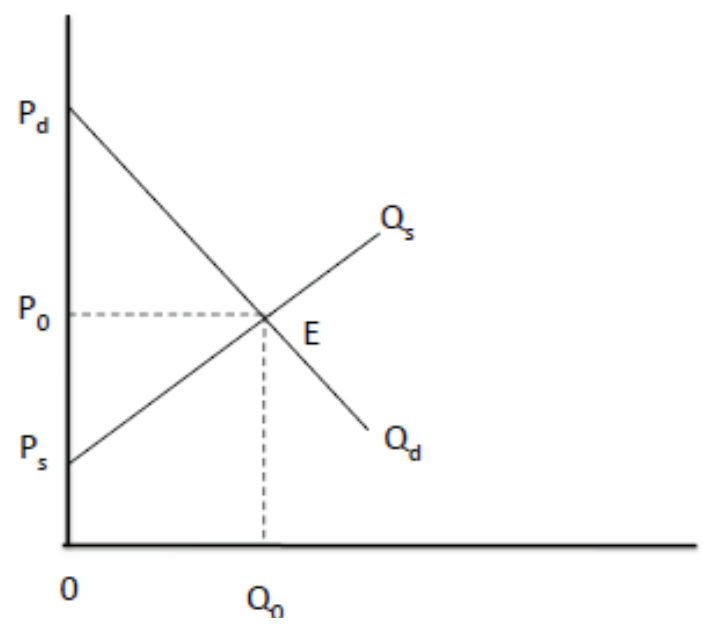

Ketika harga $(\mathrm{P})$ naik maka jumlah permintaan $\left(\mathrm{Q}_{\mathrm{d}}\right)$ turun, dan ketika harga $(\mathrm{P})$ naik maka diikuti kenaikkan kuantitas penawaran $\left(\mathrm{Q}_{\mathrm{s}}\right)$. Harga yang terbentuk, yakni Rp. 10.000,-/kg, berada pada titik keseimbangan E. Pada titik tersebut pelaku usaha mencapai surplus (segitiga $\mathrm{P}_{0}, \mathrm{P}_{\mathrm{s}}$, dan $\mathrm{E}$ ), karena harga ini merupakan harga kentang terendah yang dapat terjual. Pada titik tersebut konsumen mencapai surplus (segitiga $\mathrm{P}_{0}, \mathrm{P}_{\mathrm{d}}$, dan $\mathrm{E}$ ), karena harga yang terbentuk merupakan harga kentang tertinggi yang dapat terbeli (Chiang dan Wainwright, 2005: 31-32).

Pada saat pemerintah mengenakan pajak, maka akan menimbulkan dampak ekonomi baik bagi pelaku usaha maupun konsumen. Mengikuti gambar diatas, dampak diperlihatkan sebagai berikut. 


\section{Gambar 2}

Kondisi Post-Tax

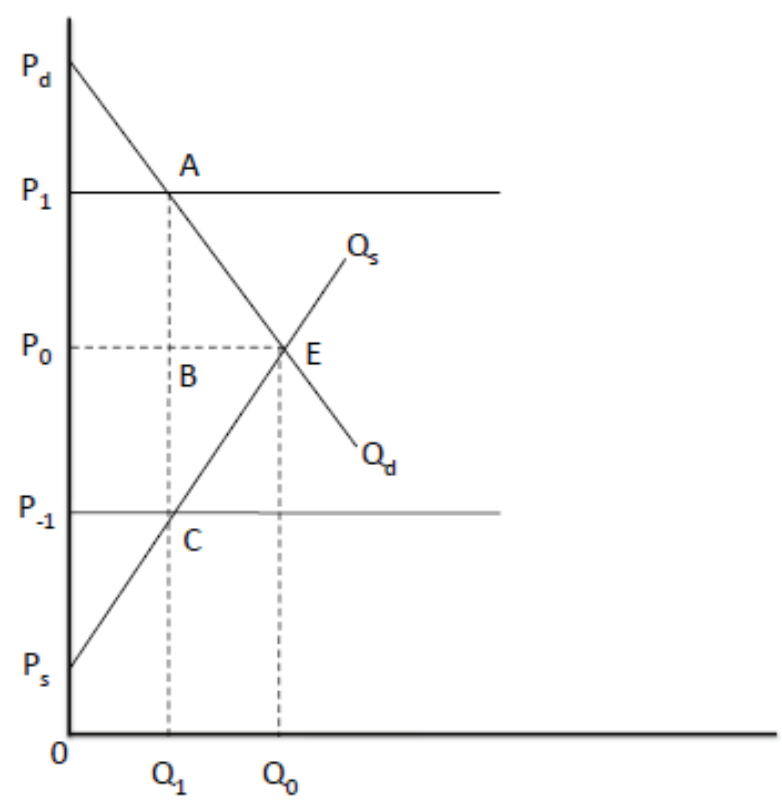

Pajak yang diberlakukan ditunjukkan persegi $\mathrm{P}_{1} \mathrm{P}_{-1} \mathrm{CA}$. Bagi konsumen, pajak menaikkan harga kentang dari $\mathrm{P}_{0}$ ke $\mathrm{P}_{1}$. Sedangkan bagi pelaku usaha, pajak menurunkan harga kentang dari $\mathrm{P}_{0}$ ke $\mathrm{P}_{-1}$. Kuantitas kentang dari turun dari $\mathrm{Q}_{0}$ ke $\mathrm{Q}_{1}$. Pergeseran harga dan kuantitas demikian mengakibatkan penurunan bobot mati (deadweight loss) bagi pelaku usaha maupun konsumen sebagaimana ditunjukkan segitiga ACE.

Misal pajak yang dikenakan sebesar 20\% per-kg kentang, maka untuk menutup transaksi, harga semula Rp. 10.000,- / kg menjadi Rp. 12.000,- / kg. Bilamana tidak ada perubahan perilaku individu, maka pemerintah menerima pemasukan sejumlah Rp. 2.000/kg kentang. Sementara bagi individu, penurunan bobot mati (deadweight loss) yang diterima lebih dari Rp. 2.000/kg kentang. Konsumen dapat membeli kebutuhan lain dengan Rp. 2.000,- tersebut, atau Rp. 2.000,- dapat digunakan pelaku usaha untuk memperbesar usahanya. Peluang ini hilang. Sampai disini jelaslah bahwa penurunan bobot mati (deadweight loss) akibat pajak tidak terelakkan. 
ljtihad: Jurnal Wacana Hukum Islam dan Kemanusiaan, Volume 18, No. 1, Juni 2018: 1-16

Berangkat dari pemahaman diatas, efisiensi dalam pajak memusatkan perhatian terhadap perbedaan perilaku individu sebelum dipungut pajak ( pre-tax) dan sesudah dipungut pajak (post-tax). Sejak setiap individu dihadapkan pada kelangkaan sumber daya, maka pajak yang efisien merupakan pemungutan pajak yang tidak mengakibatkan perubahan perilaku antara pre-tax dan post-tax. Pemungutan pajak yang tidak mengakibatkan perubahan perilaku antara pre-tax dan post-tax hanyalah dimungkinkan bilamana penurunan bobot mati (deadweight loss) yang diakibatkan pajak adalah minimal (Kaplow, 2008: 24-29).

\section{Kehati-hatian dalam perluasan pajak}

Seperti halnya hukum Islam yang mengenali perluasan pajak, rasionalitas ekonomi terhadap keberadaan pajak juga tidak membantah argumen budgeter dari pajak. Demikian juga mengenai tujuan pemungutan pajak, hukum islam menginginkan kemaslahatan total, sementara rasionalitas ekonomi mendambakan pajak yang efisien. Agar keduanya (budgeter dan kemaslahatan total/efisiensi) terpenuhi, maka ada persyaratan yang penting diperhatikan: obyek pungutan sebanyak mungkin, tunduk pada elstisitas pemintaan silang, tidak mengabaikan kesenjangan, dan administrasi yang tidak mempersulit pembayar pajak (Posner, 2014: 677).

Pertama, obyek pungutan pajak sebanyak mungkin dengan tarif moderat. Obyek pungutan pajak sebanyak mungkin dibangun melalui argumen sederhana, yakni pembagian beban budgetair kepada sebanyak mungkin individu. Artinya semakin banyak pembayar pajak diharapkan beban budgetair yang ditanggung masing-masing individu menjadi semakin ringan. Dilihat dari sirkulasi ekonomi, secara sederhana obyek pajak dapat digambarkan sebagai berikut (Case dan Fair, 2007: 405): 


\section{Gambar 3}

\section{Obyek Pajak pada Sirkulasi Ekonomi}
Obyek pajak
1. Konsumsi
2. Penjualan
3. Kekayaan Perusahaan
4. Laba
5. Pendapatan
6. Kekayaan RT

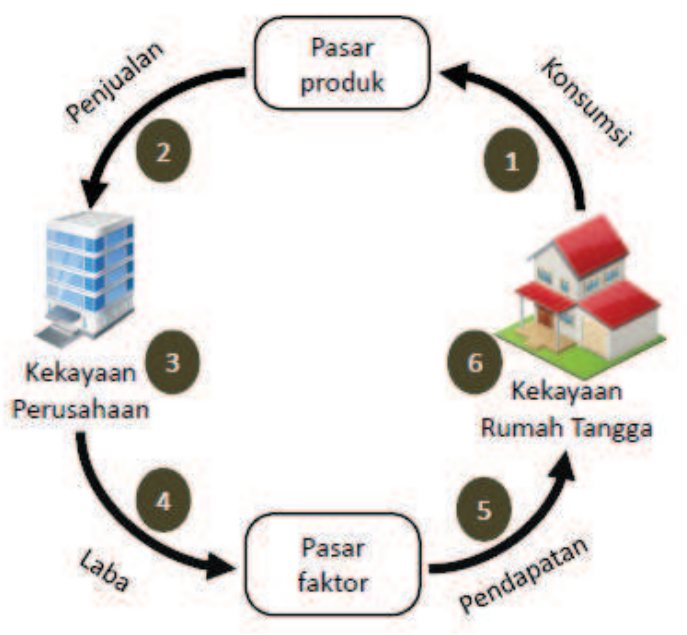

Keenam obyek pajak pada sirkulasi ekonomi tersebut dapat digolongakan menjadi 3 (tiga) kategori obyek pajak: konsumsi (obyek no. 1 dan no. 2), pendapatan/penghasilan (obyek no. 4 dan no. 5), dan kekayaan (obyek no. 3 dan no. 6). Ketiganya menjadi ukuran untuk menentukan sejauhmana kemampuan membayar (ability to pay) individu dalam menutup kewajiban perpajakannya. Ini berakar dari logika dasar ekonomika dalam mempelajari perilaku manusia terkait kelangkaan sumber daya. Logika dasar ekonomika tersebut dijadikan pedoman untuk menentukan ukuran terbaik dari kapasitas individu dalam mengontrol sumber daya terbatas yang dihadapinya.

Kembali ke obyek pungutan pajak sebanyak mungkin. Semakin banyak obyek pungutan pajak, diharapkan beban budgetair yang ditanggung masing-masing individu menjadi semakin ringan. Pertanyaannya, bilamana obyek pungutan pajak diperbanyak, mengapa negara tidak memaksimalkan pemasukan pajak melalui penentuan tarif setinggi mungkin terhadap obyek-obyek pajak tersebut? Misalnya negara menentukan menentukan tarif 90\% dari keseluruhan obyek.

Jawabannya sederhana, tarif pajak yang sangat tinggi memberikan disinsentif bagi individu untuk mengejar kesejahteraan pribadinya. Semakin banyak porsi kesejahteraan yang direduksi 
ljtihad: Jurnal Wacana Hukum Islam dan Kemanusiaan, Volume 18, No. 1, Juni 2018: 1-16

melalui pajak, semakin berkurang keinginan untuk mengejar kesejahteraan tersebut. Dalam skala ekstrim, apabila negara menerapkan pungutan pajak bertarif sangat tinggi terhadap keseluruhan obyek, maka individu tidak lagi berkeinginan untuk mempunyai pendapatan, melakukan transaksi, serta memiliki kekayaan. Hasil akhirnya ialah peneriman pajak menjadi minimal. Hubungan sebab akibat demikian yang menjadi basis penjelasan mengapa pajak bertarif sangat tinggi tidak layak diterapkan.

Kedua, penentuan obyek pajak memperhatikan elastisitas silang permintaan. Tujuan pemasukan pajak tidak akan maksimal apabila obyek yang dikenakan pajak mempunyai substitusi yang tidak dikenakan pajak atau dikenakan pajak bertarif lebih rendah. Individu akan beralih dari obyek pertama ke obyek yang kedua.

Mengikuti ilustrasi pajak kentang sub bab sebelumnya: pemerintah mengenakan pajak sebesar 20\% per-kg kentang, sehingga harga kentang semula Rp. 10.000,- / kg menjadi Rp. 12.000,- / kg. Sementara harga gandum Rp. 11.000,- / kg, dan tidak dikenakan pajak. Pengenaan pajak hanya terhadap kentang memberikan insentif individu untuk mengalihkan konsumsinya dari kentang ke gandum, baik sebagian konsumsi maupun seluruhnya. Hasil akhirnya, penerimaan pajak menjadi tidak maksimal.

Untuk memaksimalkan penerimaan pajak, maka ada 2 (dua) pendekatan dilihat dari elastisitas permintaan: (1)tarif rendah yang seragam dikenakan terhadap semua obyek pajak yang mempunyai tingkat elastisitas silang permintaan tinggi; dan (2)tarif yang tinggi dikenakan terhadap obyek pajak yang memiliki tingkat elastisitas rendah.

Misalnya pada kasus kentang dan gandum diatas. Untuk memaksimalkan penerimaan pajak, baik kentang maupun gandum, semuanya dikenakan tarif pajak sebesar $20 \%$ per-kg. Ini contoh tarif rendah untuk elastisitas silang permintaan tinggi. Sedangkan contoh tarif tinggi untuk elastisitas silang permintaan rendah dapat dijumpai pada pajak konsumsi (cukai) rokok. Sejak tidak ada substitusi yang intim dari rokok, maka pengenaan tarif tinggi adalah efisien.

Pendekatan melalui konsep elastisitas silang permintaan juga dapat digunakan untuk memprediksi serta menilai ketepatan penerapan jizyah dan kharaj. Misalnya kedua pajak diterapkan pada suatu negara. Individu non-muslim mempunyai 3 (tiga) pilihan: membayar pajak, menjadi mualaf (berpindah menjadi pemeluk islam), dan pindah negara. 
Dengan asumsi tarif kedua pajak (jizyah dan kharaj) lebih tinggi daripada tarif pajak bagi individu muslim (dharibah), maka penerimaan negara adalah maksimal bilamana individu non-muslim membayar pajak. Pilihan individu non-muslim menjadi mualaf mengakibatkan penerimaan negara menjadi berkurang dibandingkan ia tetap menjadi non-muslim, mengingat muslim masih dikenakan pajak (dharibah). Tetapi pilihan individu non-muslim untuk pindah negara, tidak menguntungkan sama sekali. Alasannya sangat jelas: negara kehilangan penerimaan pajak (baik jizyah, kharaj maupun dharibah).

Dalam skala ekstrim, individu non-muslim memilih pindah negara dan mempraktikkan transfer pricing melalui hubungan istimewa dengan individu muslim di negara yang ditinggalkannya (Septriadi dan Kristiaji, 2013: 3). Disini negara kehilangan penerimaan pajak (baik dari jizyah, kharaj, maupun dharibah), tetapi individu non-muslim tersebut justru menikmati celah pengenaan tarif yang berbeda antara individu non-muslim dan individu muslim.

Uraian diatas memperlihatkan bahwa pembedaan dalam menerapkan tarif pajak antara individu non-muslim (jizyah atau kharaj) dan pajak bagi individu muslim (dharibah) haruslah memperhatikan elastisitas silang permintaan. Dalam hal elastisitas perpindahan agama atau negara mempunyai tingkat yang rendah, maka pembedaan tarif tidak akan mengganggu penerimaan pajak. Sebaliknya, pembedaan tarif akan mengganggu penerimaan pajak bilamana elastisitas perpindahan agama atau negara memiliki tingkat yang tinggi.

Ketiga, mereduksi ketimpangan. Sebelumnya telah diuraikan bahwa dilihat dari sirkulasi ekonomi, obyek pajak dapat dikategorikan menjadi 3 (tiga): konsumsi, pendapatan, dan kekayaan. Ketiganya dijadikan pedoman untuk menentukan ukuran terbaik dari kapasitas individu dalam mengontrol sumber daya terbatas yang dihadapinya (Case dan Fair, 2007: 405). Sejak setiap individu mempunyai kapasitas yang berbeda dalam mengontrol sumber daya terbatas, maka secara alamiah ketimpangan akan hadir dalam masyarakat.

Sebagai contoh sederhana: jasa advokat yang baru selesai disumpah akan bertarif jauh lebih rendah daripada advokat yang telah berpengalaman 35 (tiga puluh lima) tahun dalam profesinya. Demikian juga pengusaha yang baru memulai bisnisnya mempunyai penghasilan lebih rendah daripada pengusaha yang kawakan. Hal sama juga terjadi pada gaji seorang office boy yang bergaji lebih rendah daripada gaji seorang manager. 
ljtihad: Jurnal Wacana Hukum Islam dan Kemanusiaan, Volume 18, No. 1, Juni 2018: 1-16

Ketimpangan sebagaimana contoh diatas selalu hadir dalam masyarakat. Ketimpangan hadir untuk menunjukkan kapasitas individu dalam mengontol sumber daya terbatas yang dihadapinya. Bilamana tidak ada pembedaan tarif antara advokat newcomer dan advokat kawakan, maka tidak ada advokat yang berinvestasi mengembangkan kemampuannya. Alasannya sederhana, kompensasi sama untuk kemampuan yang berbeda tidak memberikan insentif yang cukup (Dubner, 2005: 20).

Hanya saja gap ketimpangan yang terlalu lebar dapat menimbulkan dampak negatif, misalnya timbulnya kohesi sosial yang dalam skala ekstrim dapat mengakibatkan ketidakstabilan politik (Iryanti, 2014: 2). Sepintas, pajak (penghasilan) progresif terlihat dapat menjadi solusi untuk memecahkan permasalahan tersebut (Seligman, 1893: 52-53). Kebijakan pajak demikian dianggap menguntungkan individu yang kurang atau tidak sejahtera, karena pembebanan biaya operasional negara (budgetair) ditanggung secara progresif oleh individu yang sejahtera dan sangat sejahtera (Rawls, 2011: 12-13). Dengan skema demikian, pajak progresif dianggap mampu mengurangi gap ketimpangan penghasilan, atau setidak-tidaknya menghambat pelebaran gap ketimpangan penghasilan (Piketty, 2014: 493-512).

Untuk individu miskin tidak membayar pajak sudah tepat, karena pemungutan pajak haruslah memperhatikan standar kebutuhan dasar pembayar pajak. Tetapi tarif progresif tidaklah tepat bilamana diarahkan untuk mengurangi gap ketimpangan melalui pengalihan beban dari individu miskin kepada individu kaya dan sangat kaya. Sekurang-kurangnya ada 2 (dua) argumen, yakni pajak progresif melawan individu kaya baru dan mengganggu produktivitas (Posner, 2014: 697).

Pertama, dengan pengenaan tarif pajak berjenjang, progresif sesungguhnya melawan individu kaya baru. Apabila individu miskin sampai pada level kaya, maka ia terkena pajak progresif. Ini tidak menguntungkan si miskin yang menjadi individu kaya baru. Kedua, sebagian individu miskin yang bergantung penghasilannya dari produktivitas individu kaya menjadi terganggu oleh pajak progresif, karena pajak progresif tidak memberikan disinsentif individu kaya untuk meningkatkan produktivitasnya sehingga ia menjadi semakin kaya.

Argumen-argumen diatas memperlihatkan bahwa pajak progresif bukan hanya tidak dapat mengurangi gap ketimpangan, tetapi lebih jauh lagi, ia justru tidak menguntungkan orang yang kurang atau tidak sejahtera. Dalam jangka pendek pajak progresif mungkin akan 
meningkatkan kas negara (budgetair), tetapi tidak dalam jangka panjang.

Mengulang kembali statement sebelumnya, bahwa pajak yang baik adalah pajak yang memperpendek ketimpangan. Maka solusinya bukan dengan pajak progresif, tetapi melalui pajak proporsional. Jenis yang terakhir ini memberikan insentif yang tepat kepada individu produktif, sekaligus membiarkan individu lain mendapatkan keuntungan dari produktivitas tersebut (Posner, 2014: 697-698; an-Nabhani: 2009: 263).

Terakhir, tidak mahal biaya pengadministrasian. Ada 2 (dua) hal penting yang selayaknya diperhatikan agar individu memenuhi kewajiban perpajakannya, yakni rendahnya biaya persiapan dan disinsentif pemanfaatan celah menghindari pajak (Posner, 2014: 665-666; Kahf, 1983:152). Keduanya berhulu pada kenyataan bahwa pembayar pajak tidak mengetahui secara pasti wujud imbal balik dari pemenuhan kewajibannya (apakah berwujud jalan, jaminan keamanan, udara yang bersih dari program reboisasi, tidak menderita banjir karena pembangunan kanal sungai, fasilitas perpustakaan pemerintah, dan lain sebagainya).

Semakin rumit pengadministrasian pajak, semakin tinggi biaya persiapan yang dikeluarkan individu untuk memenuhi kewajibannya, dan semakin besar peluang pemanfaatan celah yang ada. Sehingga pengadministrasian sederhana menjadi penting untuk diindahkan terlepas dari berapapun tingkat tarif pajak yang dikenakan. Kesederhanaan pengadministrasian meliputi: kemudahaan akses informasi regulasi pajak, pemberian definisi operasional regulasi yang jelas, serta tersedianya kesempatan pembayar pajak untuk melakukan perlawanan (Thuronyi, 1996: 100-102).

\section{Penutup}

Dalam perjalanan sejarah Islam, perluasan pajak (pajak bagi individu muslim) dikenali melalui ijtihad para ahli hukum islam. Ia dikenali dengan berbagai istilah seperti daribah, al-wazăîf, al-nawäib, dan al-kulaf al-sultäniyyah. Perluasan pajak diperbolehkan sepanjang memenuhi 2 (dua) persyaratan: adanya kebutuhan menutup anggaran negara dan pemungutan tidak menimbulkan penderitaan pembayar pajak.

Rasionalitas ekonomi keberadaan pajak memperlihatkan 2 (dua) hal: pertama, keberadaan pajak penting bagi penutupan biaya yang diperlukan negara untuk penegakkan hak rakyatnya; dan kedua, keberadaan pajak mengakibatkan deadweight loss. Sehingga keberadaan pajak hanya dapat diterima bilamana deadweight loss yang diakibatkannya adalah minimal. 
ljtihad: Jurnal Wacana Hukum Islam dan Kemanusiaan, Volume 18, No. 1, Juni 2018: 1-16

Perluasan pajak dan rasionalitas ekonomi keberadaan pajak bermuara pada kesamaan dilematis dalam menghadapi pajak: ia diperlukan untuk budgetair, tetapi ia mengakibatkan penderitaan (deadweight loss). Untuk mencapai kemaslahatan bersama, maka pajak yang baik memperhatikan 4 (empat) hal: obyek pajak sebanyak mungkin agar beban terdistribusi kepada banyak individu, pajak mempertimbangkan elastisitas permintaan silang supaya tidak ada peralihan aktivitas yang dikenai pajak, pengenaan pajak harus mampu mereduksi ketimpangan bukan mempertahankan apalagi membuatnya semakin lebar, dan pengadministrasian pajak dibuat sesederhana mungkin agar pembayar pajak mempunyai insentif yang cukup untuk memenuhi kewajibannya.

\section{Daftar pustaka}

Matar, Fatima Al-. "Zakat vs Taxation: the Issue of Social Justice and Redistribution of Wealth", dalam European Journal of Business, Economics, and Accountancy Vol. 3, No. 3.

Qardhawi, Yusuf Al-. Fiqih AlZakah: a Comparative Study of Zakah, Regulations, and Philosophy in the Light of Quran and Hadist. Jeddah: Scientific Publishing Centre King Abdulaziz University, 2000.

Haritsi, Jaribah bin Ahmad Al-. Fikih Ekonomi Umar bin Al-Khathab. Jakarta Timur: Pustaka Al-Kautsar, 2015.

Mishri, Abdul Sami’ Al-. Pilar-Pilar Ekonomi Islam. Yogyakarta: Pustaka Pelajar, 2006.

Nabhani, Taqyuddin An-. Membangun Sistem Ekonomi Alternatif Perspektif Islam. Surabaya: Risalah Gusti, 2009.

As-Sadr, Muhammad Baqir. Iqtisaduna (Our Economies), Teheran: World Organization for Islamic Services, 1984.

As-Sallabi, Ali Muhammad. Umar ibn al-Khattab: His Life and Times (Vol. 1). Riyadh: International Islamic Publishing House, 2007.

Bardopoulus, Anne Michele. (The Law, Governance and Technology Series 22) eCommerce and the Effects of Technology on Taxation: Could VAT be the eTax Solution?. Heidelberg: Springer International Publishing, 2015.

Becker, Gary S. "The Economic Way of Looking at Behaviour” dalam The Journal of Political Economy Vol. 101, No. 3.

Case, Karl E., Ray C. Fair. Prinsip-Prinsip Ekonomi Jilid Kedelapan. Jakarta: Erlangga, 2007.

Chamid, Nur. Jejak Langkah Sejarah Pemikiran Ekonomi Islam. Yogyakarta: Pustaka Pelajar, 2017.

Chiang, Alpha C. Kevin Wainwright, Fundamental Methods of Mathematical Economics. New York: McGraw-Hill, 2005. 
Justifikasi hukum Islam atas pajak dalam perspektif hukum dan ekonomika (Arvie Johan)

Friedman, Milton “The Real Market Lunch: Market and Private Property" dalam Cato Policy Report, Vol. XV, No. 4.

Ghazantar, Shaikh Mohammad, Abdul Azim Islahi. Economic Thought of al-Ghazali. Jeddah: King Abdulaziz University Press, 2011.

Gusfahmi. Pajak Menurut Syariah. Jakarta: Rajawali Pers, 2011.

Haekal, Muhammad Husain. Sejarah Hidup Muhammad. Jakarta: Intermasa, 1992.

Holmes, Stephen, Cass R. Sunstein. The Cost Of Rights: Why Liberty Depends on Taxes. New York: W.W. Norron \& Company, 1999.

Iryanti, Rahma. "Kemiskinan dan Ketimpangan Indonesia: Permasalahan dan Tantangan", disampaikan pada Seminar tentang Kemiskinan, dan Ketimpangan di Indonesia: Permasalahan, Tantangan, dan Kebijakan, Fakultas Ekonomika dan Bisnis UGM, 5 September 2014.

Ismael, Tareq Y., Jacqueline S. Ismael (dengan konstribusi dari Shereen T. Ismael, Glenn E. Perry dan Ali Rezaei). Government Politics of the Contemporary Middle East: Continuity and Change. New York: Routledge, 2011.

Kahf, Monzer. "Taxation Policy in an Islamic Policy" dalam Ziauddin Ahmed, Munawar Iqbal, dan M. Fahim Khan (eds), Fiscal Policy and Resource Allocation in Islam. Islamabad: Institute of Policy Studies, 1983.

Kaplow, Louis. The Theory of Taxation and Public Economics. Princenton: Princenton University Press, 2008.

Keraf, Sonny. Hukum Kodrat dan Teori Hak Milik. Yogyakarta: Penerbit Kanisius, 1997.

Levitt, Steven D., Stephen J. Dubner. Freakonomics: A Rogue Economist Explores Hidden Side of Everything. Toronto: Harper Collins Publisher Inc., 2005.

Madaniy, A. Malik. "Pajak dalam Perspektif Fiqh Islam” dalam Al Jami'ah, No. 56.

Mercuro, Nicholas, Steven G. Medena. Economics and the Law from Posner to Post Modernism. New Jersey: Princeton University Press, 1999.

Mertokusumo, Sudikno. Mengenal Hukum Suatu Pengantar, Yogyakarta: Liberty, 2005.

Musa, Ibnu Said bin Muhammad. Nasehat Bijak tuk Para Pemungut Pajak. Jakarta: Darul Qolam, 2005.

Nozick, Robert. Anarchy, State, and Uthopia. Oxford: Blackwell, 1999.

Piketty, Thomas. Capital in the Twenty-First Century. Massachusetts: The Belknap Press of Harvard University, 2014.

Posner, Richard. Economic Analysis of Law (Ninth Edition). New York: Wolters Kluwer Law \& Business, 2014.

Pusat Pengkajian dan Pengembangan Ekonomi Islam UII kerjasama dengan Bank Indonesia. Ekonomi Islam. Jakarta: Rajawali Pers, 2015. 
ljtihad: Jurnal Wacana Hukum Islam dan Kemanusiaan, Volume 18, No. 1, Juni 2018: 1-16

Rawls, John. Teori Keadilan: Dasar-Dasar FilsafatPolitik untuk. Mewnjudkan Kesejabteraan Sosial dan Negara. Yogyakarta: Pustaka Pelajar, 2011.

Saeed, Abdullah. Reading the Qur'an in the Twenty-First Century: A Contextualist Approach. New York: Routledge, 2014,.

Salanie, Bernard. The Economics of Taxation. Massachusetts: The MIT Press, 2003.

Seligman, Edwin R.A. "The Theory of Progressive Taxation" dalam Publications of American Economic Association Vol. 8, No. 1.

Septriadi, Danny, B. Bawono Kristiaji, Transfer Pricing: Ide, Strategi, dan Panduan Praktis dalam Perspektif Perpajakan Internasional. Jakarta Danny Darussalam Tax Center, 2013.

Shapiro, Ian, Evolusi Hak dalam Teori Liberal. Jakarta: Yayasan Obor Indonesia, 2006.

Soehino, Ilmu Negara. Yogyakarta: Liberty, 2005.

Victor Thuronyi, Tax Law Design and Drafting. Washington: IMF, 1996.

Wibisana, Wahyu, "Pendapat Ibnu Taymiyyah tentang Keuangan Publik" dalam Jurnal Pendidikan Agama Islam - Ta'lim Vol. 14, No. 1.

Yahya, Mukhtar, Fatcurrahman, Dasar-Dasar Pembinaan Hukum Fiqh Islami. Bandung: Al-Ma'arif, 1986. 